\title{
Immunological and clinical consequences of splenectomy in a multiple sclerosis patient treated with natalizumab
}

\author{
De-Hyung Lee ${ }^{1 \dagger}$, Anne Waschbisch ${ }^{1 \dagger}$, Alexandra B Lämmer ${ }^{1}$, Arnd Doerfler ${ }^{2}$, Stefan Schwab ${ }^{1}$ and Ralf A Linker ${ }^{1 *}$
}

\begin{abstract}
Objective: Here we report a case of a splenectomized white woman with natalizumab-associated progressive multifocal leukoencephalopathy (PML), occurring as early as after 11 infusions and provide blood fluorescenceactivated cell sorting (FACS) analyses before and after natalizumab treatment.
\end{abstract}

Design: This is a report of a single case with immunological studies.

Methods: Methods comprised neurologic examination, magnetic resonance imaging, and cerebrospinal fluid (CSF) studies as well as immune cell FACS analyses from blood.

Results: Diagnosis of PML was established after positive John Cunningham virus (JCV) DNA was detected in the CSF. An immune reconstitution inflammatory syndrome was treated with repeated cycles of steroid pulses and intravenous immunoglobulins. Reduced numbers of memory B cells, which might play an important role in antiviral immune response, were detected in the blood. Moreover the percentage of CD19+ B cells was elevated in our post-splenectomy patient as compared to a control cohort of multiple sclerosis (MS) patients under natalizumab therapy.

Conclusion: Splenectomy may increase the risk for the development of natalizumab-associated PML via effects on the B cell compartment. It may be regarded as a risk factor in MS patients independent from the duration of disease.

Keywords: Progressive multifocal leukoencephalopathy, Multiple sclerosis, Natalizumab, Splenectomy, CD19 positive B cells

\section{Background}

Before the era of natalizumab as first monoclonal antibody in multiple sclerosis (MS) therapy arose, progressive multifocal leukoencephalopathy (PML), which is caused by the John Cunningham polyoma virus (JCV), was more or less exclusively seen in immunocompromised individuals, especially those suffering from human immunodeficiency virus (HIV) infection [1,2]. Natalizumab is a highly effective treatment option for relapsing remitting MS with positive data from the pivotal phase III trial yielding a reduction in annual relapse rate by $68 \%$ and a reduction

\footnotetext{
* Correspondence: Ralf.Linker@uk-erlangen.de

${ }^{\dagger}$ Equal contributors

'Department of Neurology, Friedrich Alexander University of Erlangen-

Nuremberg, Schwabachanlage 6, Erlangen 91054, Germany

Full list of author information is available at the end of the article
}

in disability progression over $42 \%$ versus placebo [3]. Yet, a rare but potentially severe adverse event of natalizumab is the development of PML. At present, there are more than 350 cases of natalizumab-associated PML reported worldwide, with an overall incidence of $2.5 / 1,000$. Treatment with unselective immunosuppressants displays an independent epidemiologic risk factor for the development of PML, especially after 24 months of treatment duration [4]. These data suggest that the probability to develop a PML might be associated with an impaired integrity of the immune system. To date, the exact immune factors contributing to an increased PML susceptibility are still not clearly defined. In particular, there are no data on the role of the spleen for immune responses against JC virus in MS patients. The spleen plays a key role in the homeostasis of the immune system. By linking the innate

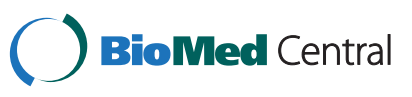

(C) 2013 Lee et al.; licensee BioMed Central Ltd. This is an open access article distributed under the terms of the Creative Commons Attribution License (http://creativecommons.org/licenses/by/2.0), which permits unrestricted use, distribution, and reproduction in any medium, provided the original work is properly cited. 
and adaptive immune system, it orchestrates the immune defense that protects from infections [5]. In splenectomized individuals, absolute lymphocyte counts are persistently elevated due to an increase in the absolute CD4, CD8, B cell, and natural killer (NK) cell numbers [6]. Similar changes can be observed in natalizumabtreated patients $[7,8]$. Moreover, natalizumab treatment may elicit prominent effects on the composition of the circulating B cell populations. In particular circulating B cells and especially pre-B cells are most prominently elevated among the immune cell subsets [9-11]. Likewise dominant changes on the peripheral blood B cell compartment have also been observed in splenectomized patients. Natalizumab associated changes have been attributed to the mobilization of hematopoetic precursor cells from the bone marrow and a redistribution of cells due to the inhibition of leukocyte migration and homing to secondary lymphoid organs [12-14]. Splenectomy and natalizumab may thereby have synergistic effects on the immune cell composition of the peripheral blood thus increasing the risk for PML.

\section{Methods}

Peripheral blood mononuclear cells (PBMC) were isolated by centrifugation on a Lymphoprep ${ }^{\text {тм }}$ (Fresenius Kabi Norge AS, Oslo, Norway) density gradient. To allow comparative longitudinal analysis, PBMC were immediately cryopreserved. Blood from our PML patient had been drawn 22 months before the primary diagnosis of PML. At that time the patient was not treated with disease modifying drugs $\left(\mathrm{T}_{0}\right)$. The second blood sample $\left(\mathrm{T}_{1}\right)$ was drawn when the patient was hospitalized for PML, the third sample $\left(\mathrm{T}_{2}\right)$ was obtained 21 days later. Results of our splenectomized patients were compared with a control cohort of MS patients under natalizumab therapy (mean age, 34.4 years; range, 24-43 years; female to male ratio, 3.5:1; mean disease duration, 7.8 years; range, 2-16 years; mean expanded disability status scale (EDSS), 2.95; range, 1.55.5). After gentle thawing, cells were washed twice in phosphate buffered saline (PBS) containing $0.1 \%$ sodium azide and $1 \%$ bovine serum albumine, followed by Fc receptor blocking with human IgG (Sigma-Aldrich, Munich, Germany). Afterwards, cells were incubated for $30 \mathrm{~min}$ with specific monoclonal antibodies. The $\mathrm{B}$ cell gating strategy of fluorescence-activated cell sorting (FACS) analysis has been provided as Additional file 1: Figure S1. The following anti-human monoclonal antibodies (clone) and the respective isotype control antibodies were used (all fluorochrome-conjugated): anti-CD19 FITC (HIB19, BD Biosciences), anti-CD27 efluor ${ }^{\circ} 450$ (O323, ebioscience), anti-IgM PE (SA-DA4, ebioscience), anti-IgD PerCP-CY5.5 (IA6-2, Biolegend). Cells were analyzed on a FACSCanto ${ }^{\mathrm{mm}}$ II using the FACSDiva ${ }^{\text {тм }}$ Software (BD Biosciences, Heidelberg, Germany).

\section{Case presentation}

At the age of 4 years, a now 34-year-old white woman underwent splenectomy after a neonatal omphalitis with portal vein thrombosis and esophageal varices. The incidence of common infections during child- as well as adulthood was not increased in comparison to healthy persons indicating a generally intact immunological response. At the age of 19 years, the patient noticed sensory disturbances in the feet with unsteadiness both of which resolved spontaneously. Five years later she was admitted to an outside hospital due to a hemiparesis of the left side where the diagnosis of a MS was established. Magnetic resonance imaging (MRI) of the brain revealed several periventricular lesions as well a gadolinium-enhancing lesion. Analysis of cerebrospinal fluid presented oligoclonal bands. At that time, an immunomodulatory therapy with interferon beta 1a i.m. was started. In the following 3 years, the patient suffered from four further relapses. Each time, high dose intravenous methylprednisolone pulses were applied and the patient recovered completely. After the fourth relapse, EDSS was 2.0 (see clinical course in Figure 1A). Over the following 5 years, adherence to disease-modifying therapy was poor. Consequently, the patient presented a severe relapse with paraparesis and EDSS progressed from 2.0 to EDSS 6.0 (Figure 1A). At that time, loss of her working ability as a clerk accountant was incipient and the patient was no longer able to independently care for her 9-year-old son. Thus, an escalation therapy with natalizumab was initiated which led to stabilization of the disease without further relapses and an improvement of EDSS to 2.5 (Figure 1A). After the 11th application of natalizumab, the patient developed a paresis of the right leg, which was initially considered as a relapse at an outside clinic where the patient received a high dose intravenous methylprednisolone pulse without success. Upon re-evaluation in our Department, the MRI scan of the brain showed a linear fronto-parietal cortical lesion with a very faint gadolinium enhancement (Figure 1B). A subsequently performed cerebrospinal fluid analysis revealed 30 copies of JC virus DNA and the JC virus antibody assay was positive (this test was not yet available at the beginning of therapy). The patient immediately underwent plasmapheresis therapy with five cycles for natalizumab elimination. On the basis of expert recommendations, a therapy with mirtazapine at a dosage of $60 \mathrm{mg}$ and mefloquine $1,500 \mathrm{mg}$ the first week and then $250 \mathrm{mg}$ weekly was initiated. In the next months, repeated MRI scans after PML diagnosis of the brain presented an increase of the right fronto-parietal lesion volume with gadolinium enhancement (Figure 1B). These findings correlated with the development of a paresis oft the right hand and focal epileptic seizures of the right hand, indicating the clinical deterioration of 


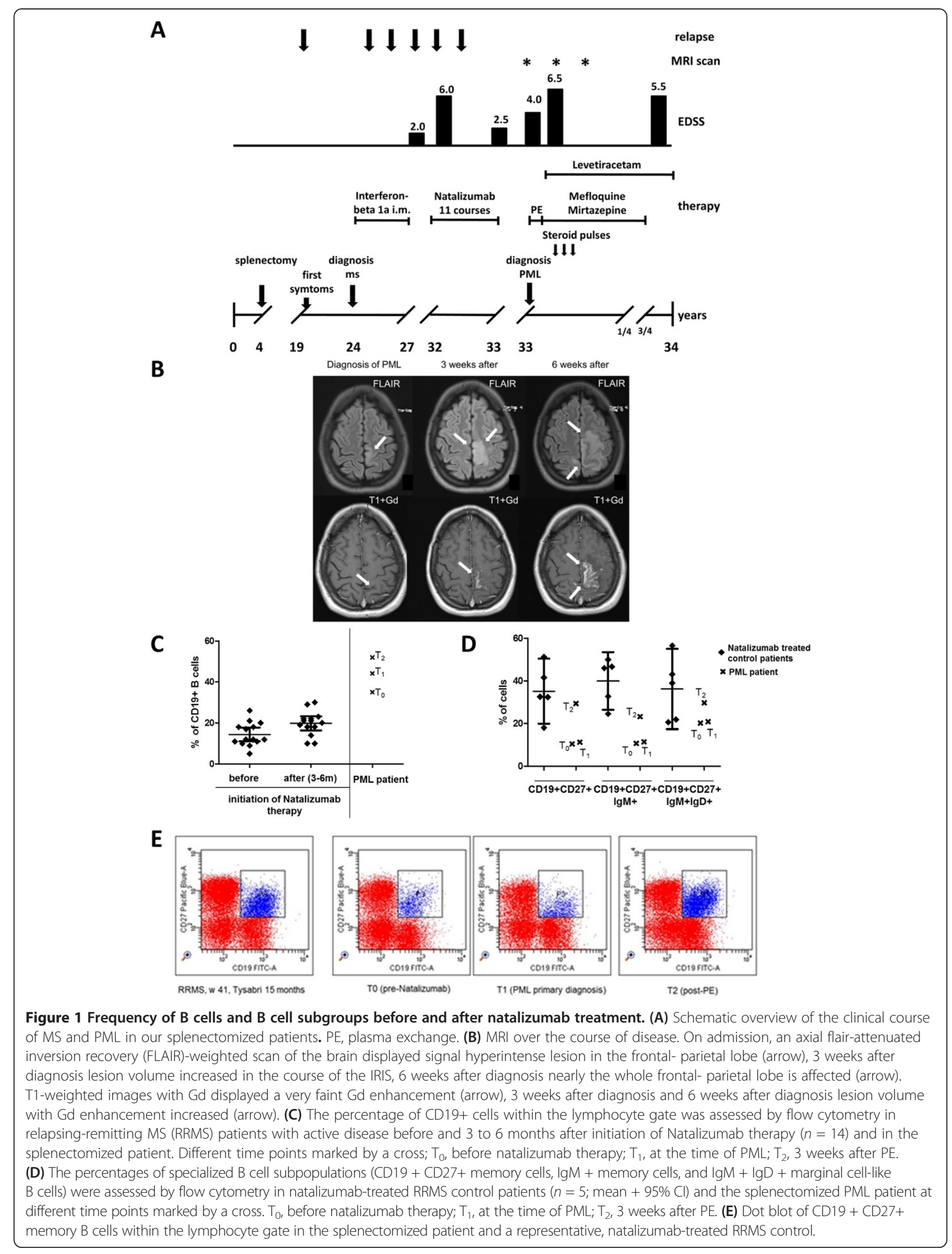


neurological deficits during the immune reconstitution inflammatory syndrome (IRIS) after elimination of natalizumab. An antiepileptic therapy with levetiracetam was started and the patient received repeated high-dose methylprednisolone intravenously (total dosage of 20,000 $\mathrm{mg}$ in three cycles, see Figure 1A). Six weeks after diagnosis of PML was made, EDSS deteriorated from 4.0 to 6.5 and the patient additionally showed symptoms of major depression. Six months after the diagnosis of PML, MRI scans of the brain for the first time revealed a reduction of lesion volume and gadolinium enhancement (Figure 1B). No further focal epileptic seizures occurred and the paresis of the right hand as well as symptoms of depression completely resolved. Nine months after diagnosis of PML, the patient started to work again, although EDSS was still 5.5. The last MRI scan performed 10 months after diagnosis of PML revealed one new periventricular lesion without gadolinium enhancement. The PML lesion still showed a slight gadolinium uptake while lesion volume did no change any more (Figure $1 \mathrm{~B})$. So far, the patient refused to re-start any new immunomodulatory therapy.

Using flow cytometry, we analyzed the percentage of CD19 positive (+) B cells within the lymphocyte gate in active MS patients before and 3 to 6 months after initiation of natalizumab therapy $(n=14)$. Before treatment, CD19+ B cells accounted for $14.2 \pm 5.5 \%$ of lymphocytes (361 \pm 159 cells $/ \mu \mathrm{L})$ and increased to $21.8 \pm 5.5 \%(876+/-325$ cells $/ \mu \mathrm{L})$ under natalizumab therapy. In contrast, the percentage of CD19+ B cells in our splenectomized patient was $35.1 \%(576 / \mu \mathrm{L})$ even before starting on natalizumab $\left(\mathrm{T}_{0} ;>3\right.$-fold $\left.\mathrm{SD}\right)$ (Figure $1 \mathrm{C}$ ). At the time of PML $\left(\mathrm{T}_{1}\right)$ the percentage of $\mathrm{CD} 19+\mathrm{B}$ cells within the lymphocyte gate had increased to $44.2 \%$ (approximately four-fold SD of natalizumab-treated patients; $1,303 / \mu \mathrm{L})$ and remained high even after plasma exchange (PE) $\left(\mathrm{T}_{2} ; 52.0 \%, 15\right.$ days post $\mathrm{PE} ; 868 / \mu \mathrm{L}$ ) (Figure 1C). B cell subpopulations were further analyzed in $n=5$ natalizumab-treated MS patients without PML. A total of $34.2 \pm 11.2 \%$ of CD19+ B cells displayed a $\mathrm{CD} 27+$ memory phenotype which is within the range of published data on memory B cells in these patients [4]. In contrast, the percentage of CD27+ memory B cells was considerably lower in our patient both before natalizumab $\left(\mathrm{T}_{0} ; 10.5 \%\right.$ of CD19+ cells) and at the time of PML $\left(\mathrm{T}_{1}\right.$; $11.3 \%$ of CD19+ cells) (Figure 1D and E). Following PE, we observed a disproportional rise in CD27+ memory B cells $\left(\mathrm{T}_{2} ; 29.4 \%\right.$ of CD19+ cells) (Figure 1D and E). Comparable observations were made for the $\operatorname{IgM}+$ population of memory B cells $\left(\mathrm{T}_{0} ; 10.8, \mathrm{~T}_{1} ; 11.5 \%, \mathrm{~T}_{2} ; 23.2 \%\right.$, data given as $\%$ of memory cells). In contrast, IgM + memory B cells accounted for $40.0 \pm 10.9 \%$ of memory B cells in our natalizumab-treated control group. Marginal cell-like CD19+ CD27 + IgM + IgD + B cells accounted for $36.2 \pm$ $15.2 \%$ of $\mathrm{B}$ cells in the natalizumab group, which is within the range of previously published data on long-term treated patients [4] (Figure 1D). In our patient, the percentage of marginal cell-like B cells tended to be lower as compared to the controls $\left(\mathrm{T}_{0}, 20.2 \% ; \mathrm{T}_{1}, 20.9 \% ; \mathrm{T}_{2}, 29.0 \%\right)$ but was still within the two-fold of standard deviation of the controls.

\section{Discussion}

Although the development of PML under natalizumab is extremely rare in the first year of therapy even in patients with a history of immunosuppression, this immunosuppressant-therapy naïve splenectomized MS patient developed a PML after only 11 infusions.

B cells are susceptible to JC virus infection and have been implicated in the reactivation and central nervous system (CNS) transmigration of the virus. Following the start of natalizumab therapy, the percentage of circulating $B$ cells increases disproportionately $[9,10]$. A selective mobilization of $\mathrm{B}$ cells may thus be relevant for PML development by propagation of JCV dissemination. In addition, B cells may serve as a carrier that transports the virus to the CNS [15]. The spleen is regarded the most important reservoir of memory B cells. In addition, the spleen is the tissue that, if tested positive for JCV DNA, harbors the highest diversity of sequence rearrangements within the JCV regulatory region [9,16-18]. Splenectomy has wide-ranging consequences for immune cell homeostasis. Especially the B cell compartment seems to be affected. The percentage of CD19+ B cells among the lymphocyte population may be elevated in some but certainly not all post-splenectomy patients irrespective of the reason for splenectomy, that is trauma or hematological disease $[19,20]$. Yet, an increase in the percentage of circulating B cells is per se not considered a risk factor for infection in post-splenectomy patients. Our patient had an extraordinary high percentage of CD19+ lymphocytes within the peripheral blood that - as would be expected even further increased under the influence of natalizumab. Given the possible role of B cells in JC virus propagation, we cannot exclude that the high pre-treatment percentage of B lymphocytes may have contributed to PML in our patient. However, the perturbed B cell memory compartment may have been the more crucial factor. Our patient had low percentages of both CD27+ and CD27 + IgM + memory B cells. This is a common finding following splenectomy [5,19]. Assessing IgM memory B cell frequency has therefore been proposed as a potential parameter for evaluation of splenic function or risk of infection following splenectomy [19,21]. Natalizumab treatment was reported to selectively mobilize memory B cells in MS patients which was considered to be secondary to an impaired retention of memory cells in the splenic marginal zone and gut-associated lymphoid tissue (GALT) by blocking very late antigen (VLA)-4/vascular cell adhesion molecule (VCAM)-1 interaction and downregulation of 
lymphocyte function associated antigen (LFA)-1 and alpha4-beta1 integrin [9]. In our splenectomized patient, memory B cell levels remained low under natalizumab therapy and only increased after PE. Similar observations were made for CD27 + IgM + IgD + B cells that tended to be lower in our patient. These circulating marginal zonelike B cells are considered to derive from the splenic marginal zone where these cells play an important role in the generation of $\mathrm{T}$ cell independent antibody responses [22]. The source for the increase in memory B cells 3 weeks following natalizumab elimination by PE in our patient is not clear but may be attributed to the GALT. We here present data of one individual only, which is a limitation of this study. In addition, our patient had been treated with glucocorticoids before diagnosis of PML was established. Since glucocorticoid treatment may affect immune cell composition of the peripheral blood, we cannot exclude that this has biased our findings. However, the profound reduction of the memory $\mathrm{B}$ cell population has repeatedly been demonstrated in splenectomized patients and therefore more likely to be due to the status post-splenectomy and not the glucocorticoid treatment [19]. Thus, given the prominent role of memory B cells in antiviral immune responses, splenectomy may represent a risk factor for PML under natalizumab therapy.

\section{Conclusions}

Splenectomy may increase the risk for the development of natalizumab associated PML affecting the B cell compartment and should regarded as a risk factor in MS patients independent from the duration of disease. If therapy with natalizumab is considered in a splenectomized MS patient, benefits of the therapy should be well balanced with the possibly increased risk for the development of PML.

\section{Consent}

The study was approved by the local ethics committee and written consent was obtained from all participants for publication of this case report and any accompanying images.

\section{Additional file}

Additional file 1: Figure $\mathbf{S 1}$. Gating strategy used to assess the frequency of CD19+ B cells, CD19+ CD27+ memory cells, lgM + memory cells and $\lg M+\lg D+$ marginal cell-like $B$ cells within the peripheral blood.

\section{Abbreviations}

CD: Cluster of differentiation; CNS: Central nerve system; CSF: Cerebrospinal fluid; DNA: Deoxyribonucleic acid; EDSS: Expanded disability status scale; FLAIR: Flair-attenuated inversion recovery; GALT: Gut-associated lymphoid tissue; Gd: Gadolinium; HIV: Human immunodeficiency virus; IRIS: Immune reconstitution inflammatory syndrome; JCV: John Cunningham virus; LFA: Lymphocyte function associated antigen; MRI: Magnetic resonance imaging; MS: Multiple sclerosis; NK: Natural killer; PML: Progressive multifocal leukoencephalopathy; VCAM: Vascular cell adhesion molecule.

\section{Competing interests}

The authors declare that they have no competing interest.

\section{Authors' contributions}

$\mathrm{DL}$ and $\mathrm{AW}$ took the lead in drafting the manuscript and have made substantial contributions to the study concept and design, analysis and interpretation of data, and statistical analysis. AW carried out FACS analyses. $A L$ and SS were involved in drafting the manuscript, and made substantial contributions to the acquisition, analysis, and interpretation of data. $\mathrm{AD}$ made substantial contributions to the acquisition, analysis, and interpretation of MRI data. RL was involved in drafting the manuscript and in revising it critically for important intellectual content, and made substantial contributions to study the concept and design, and analysis and interpretation of laboratory data. All authors read and approved the final manuscript.

\section{Acknowledgement}

We wish to thank Kathrin Bitterer for excellent support and all our patients for blood samples. This study was supported by the Else-Kröner-FreseniusStiftung project 2011 A123

\section{Author details}

${ }^{1}$ Department of Neurology, Friedrich Alexander University of ErlangenNuremberg, Schwabachanlage 6, Erlangen 91054, Germany. '2Department of Neuroradiology, Friedrich Alexander University of Erlangen-Nuremberg, Schwabachanlage 6, Erlangen 91054, Germany.

Received: 2 June 2013 Accepted: 24 September 2013

Published: 9 October 2013

\section{References}

1. Holman RC, Torok TJ, Belay ED, Janssen RS, Schonberger LB: Progressive multifocal leukoencephalopathy in the United States, 1979-1994: increased mortality associated with HIV infection. Neuroepidemiology 1998, 17:303-309.

2. Brooks BR, Walker DL: Progressive multifocal leukoencephalopathy. Neurol Clin 1984, 2:299-313.

3. Polman $\mathrm{CH}, \mathrm{O}^{\prime}$ Connor PW, Havrdova E, Hutchinson M, Kappos L, Miller DH, Phillips JT, Lublin FD, Giovannoni G, Wajgt A, Toal M, Lynn F, Panzara MA, Sandrock AW, AFFIRM Investigators: A randomized, placebo-controlled trial of natalizumab for relapsing multiple sclerosis. N Engl J Med 2006, 354:899-910.

4. Bloomgren G, Richman S, Hotermans C, Subramanyam M, Goelz S, Natarajan A, Lee S, Plavina T, Scanlon JV, Sandrock A, Bozic C: Risk of natalizumabassociated progressive multifocal leukoencephalopathy. N Engl J Med 2012, 366:1870-1880.

5. Di Sarbatino A, Carsetti R, Corazza GR: Post-splenectomy and hyposplenic states. Lancet 2011, 378:86-97.

6. Karakantza M, Theodorou GL, Mouzaki A, Theodori E, Vagianos C, Maniatis A: In vitro study of the long-term effects of post-traumatic splenectomy on cellular immunity. Scand J Immunol 2004, 59:209-219.

7. Ransohoff RM: Natalizumab and PML. Nat Neurosci 2005, 8:1275.

8. Lindberg RL, Achtnichts L, Hoffmann F, Kuhle J, Kappos L: Natalizumab alters transcriptional expression profiles of blood cell subpopulations of multiple sclerosis patients. J Neuroimmunol 2008, 194:153-164.

9. Planas R, Jelcic I, Schippling S, Martin R, Sospedra M: Natalizumab treatment perturbs memory- and marginal zone-like B-cell homing in secondary lymphoid organs in multiple sclerosis. Eur J Immunol 2012, 42:790-798.

10. Krumbholz M, Meinl I, Kumpfel T, Hohlfeld R, Meinl E: Natalizumab disproportionately increases circulating pre-B and B cells in multiple sclerosis. Neurology 2008, 71:1350-1354.

11. Bornsen $L$, Christensen JR, Ratzer R, Oturai AB, Sorensen PS, Sondergaard $H B$, Sellebjerg F: Effect of natalizumab on circulating CD4+ T-cells in multiple sclerosis. PLoS One 2012, 7:e47578.

12. Saure C, Warnke C, Zohren F, Schroeder T, Bruns I, Cadeddu RP, Weigelt C, Fischer U, Kobbe G, Hartung HP, Adams O, Kieseier BC, Haas R: Natalizumab and impedance of the homing of $\mathrm{CD} 34+$ hematopoietic progenitors. Arch Neurol 2011, 68:1428-1431.

13. Bonig H, Wundes A, Chang KH, Lucas S, Papayannopoulou T: Increased numbers of circulating hematopoietic stem/progenitor cells are 
chronically maintained in patients treated with the CD49d blocking antibody natalizumab. Blood 2008, 111:3439-3441.

14. Warnke C, Smolianov V, Dehmel T, Andrée M, Hengel H, Zohren F, Arendt G, Wiendl H, Haas R, Hartung HP, Adams O, Kieseier BC: CD34+ progenitor cells mobilized by natalizumab are not a relevant reservoir for JC virus. Mult Scle 2011, 17:151-156.

15. Chapagain ML, Nerurkar VR: Human polyomavirus JC (JCV) infection of human B lymphocytes: a possible mechanism for JCV transmigration across the blood-brain barrier. J Infect Dis 2010, 202:184-191.

16. Marousi S, Karkanis I, Kalamatas T, Travasarou M, Paterakis G, Karageorgiou CE: Immune cells after prolonged Natalizumab therapy: implications for effectiveness and safety. Acta Neurol Scand 2013, 128:e1-e5.

17. Caldarelli-Stefano R, Vago L, Omodeo-Zorini E, Mediati M, Losciale L, Nebuloni M, Costanzi G, Ferrante P: Detection and typing of JC virus in autopsy brains and extraneural organs of AIDS patients and non-immunocompromised individuals. J Neurovirol 1999, 5:125-133.

18. Houff SA, Major EO, Katz DA, Kufta CV, Sever JL, Pittaluga S, Roberts JR, Gitt J, Saini N, Lux W: Involvement of JC virus-infected mononuclear cells from the bone marrow and spleen in the pathogenesis of progressive multifocal leukoencephalopathy. N Engl J Med 1988, 318:301-305.

19. Cameron PU, Jones P, Gorniak M, Dunster K, Paul E, Lewin S, Woolley I, Spelman D: Splenectomy associated changes in IgM memory B cells in an adult spleen registry cohort. PLOS One 2011, 6:e23164.

20. Millard RE, Banerjee DK: Changes in T and B blood lymphocytes after splenectomy. J Clin Pathol 1979, 32:1045-1049.

21. De Porto AP, Lammers AJ, Bennink RJ, ten Berge IJ, Speelman P, Hoekstra JB: Assessment of splenic function. Eur J Clin Microbiol Infect Dis 2010 29:1465-1473.

22. Weller S, Braun MC, Tan BK, Rosenwald A, Cordier C, Conley ME, Plebani A, Kumararatne DS, Bonnet D, Tournilhac O, Tchernia G, Steiniger B, Staudt LM Casanova JL, Reynaud CA, Weill JC: Human blood IgM "memory" B cells are circulating splenic marginal zone $B$ cells harboring a prediversified immunoglobulin repertoire. Blood 2004, 104:3647-3654.

doi:10.1186/1742-2094-10-123

Cite this article as: Lee et al:: Immunological and clinical consequences of splenectomy in a multiple sclerosis patient treated with natalizumab. Journal of Neuroinflammation 2013 10:123.

\section{Submit your next manuscript to BioMed Central and take full advantage of:}

- Convenient online submission

- Thorough peer review

- No space constraints or color figure charges

- Immediate publication on acceptance

- Inclusion in PubMed, CAS, Scopus and Google Scholar

- Research which is freely available for redistribution 